\author{
JOANNA T. WOŹNA \\ Instytut Zoologii \\ Uniwersytet Przyrodniczy $w$ Poznaniu \\ Wojska Polskiego 71 C, 60-625 Poznań \\ E-mail: jtwozna@gmail.com
}

\title{
OSOBOWOŚĆ U PTAKÓW - ZAŁOŻENIA TEORETYCZNE, KIERUNKI I METODY BADAŃ
}

\section{WSTEP}

Różnice w zachowaniach zwierząt możemy obserwować na trzech poziomach: międzygatunkowym, międzypopulacyjnym i osobniczym. $Z$ zachowaniem osobniczym zwiazane jest zjawisko osobowości, które definiuje się jako zespół względnie stałych cech zachowania, charakterystycznych dla osobnika, które towarzysza zwierzęciu niezmienione przez całe życie (STAMPS i GroOthuis 2010). Istnienie osobowości u zwierząt wykazano $\mathrm{u}$ wielu taksonów, m. in. u ssaków, ptaków, gadów, ryb, głowonogów i stawonogów. Obecnie badania osobowości skupiaja się przede wszystkim na jej znaczeniu ekologicznym oraz ewolucyjnym i dotyczą w szczególności ptaków (GROOTHUIS i CARERE 2005).

Badania nad osobowościa zwierzat rozpoczęto w latach 70. XX w. (BURTT i GILTZ 1973). Wcześniej badania behawioralne miały charakter populacyjny. Unikano wówczas stosowania tych samych pojęć, które używane sa w psychologii (GROOTHUIS i CARERE 2005). Niektóre terminy (strach, zdenerwowanie) mogłyby zostać błędnie zinterpretowane, ponieważ nie zawsze odnosza się do tych samych stanów fizjologicznych u ludzi i zwierzą (RÉALE i współaut. 2007). Nie oznacza to jednak, że zanim termin „osobowość" zaczą być używany w odniesieniu do zwierzat, badania $\mathrm{w}$ tej dziedzinie nie miały miejsca. Badano konkretne cechy osobowości, takie jak poziom agresji, ale autorzy nie przypisywali ich do szerszej kategorii jaka jest osobowość (BURTT i GiLTZ 1973, GosLing 2001). Prawdziwy postęp w tej dziedzinie rozpoczał się jednak w latach 90. XX w., a obecnie badania dotycza między innymi wpływu różnych czynników zewnętrznych na osobowość zwierzat, jej zmian w trakcie życia osobnika i roli, jaka odgrywaja geny w tworzeniu osobowości (STAMPS i GROOTHUIS 2010).

Niniejsza praca ma na celu przybliżenie zagadnienia osobowości ptaków na różnych poziomach rozważań. W pierwszej kolejności przedstawione zostały wyznaczniki osobowości, czyli cechy, w oparciu o które określane sa poszczególne typy osobowości. Sa to przede wszystkim cechy zachowania, choć $z$ typem osobowości ściśle moga być zwiazane również wyznaczniki morfologiczne, takie jak kolor upierzenia. W kolejnych rozdziałach omówione zostały zagadnienia zwiąane $z$ ewolucja cech osobowości - związki między osobowościa a doborem płciowym i presja selekcyjna, które działaja na osobniki, a także między osobowościa a przeżywalnościa i sukcesem rozrodczym ptaków. Na koniec podsumowano, sięgajace do endokrynologii i genetyki, badania sposobów determinowania cech osobowości.

\section{BEHAWIORALNE WYZNACZNIKI OSOBOWOSCI PTAKOWW}

Typy osobowości określa się w oparciu o cechy zachowania, powtarzalne $\mathrm{w}$ czasie $\mathrm{i}$ w różnych kontekstach (np. w sytuacji zagrożenia, podczas inkubacji jaj, podczas żerowania itp). Sa to: szybkość eksploracji nowych środowisk, agresja, zachowania innowacyjne, dystans ucieczki, skłonność do ryzyka czy nawet śpiew, które traktuje się jako wyznaczniki osobowości. 
Osobniki możemy podzielić na szybko i wolno eksplorujace środowisko. Eksploracja jest tu rozumiana jako gromadzenie informacji $\mathrm{w}$ celu zapoznania się osobnika $\mathrm{z}$ nowopowstała sytuacja, która, w badaniach nad eksploracyjnościa, jest np. generowana przez eksperymentatora zmiana w dostępności pokarmu. Osobniki szybkie eksploruja środowisko bardziej pobieżnie, natomiast wolne robia to uważniej (DRENT i MARCHETTI 1999). Eksploracyjność jest najczęściej stosowanym wskaźnikiem osobowości, badanych według schematu zaproponowanego przez DingEMANSE i współaut. (2002). Test polega na obserwowaniu zachowania ptaków w pomieszczeniu eksperymentalnym, zaopatrzonym w pięć sztucznych drzew. Jako wskaźnik eksploracyjności bierze się pod uwagę liczbę przelotów i skoków badanego osobnika w toku eksperymentu. Wyniki badań bogatek Parus major wskazuja na powtarzalność zachowań eksploracyjnych zarówno u samców, jak i u samic (DingEMANSE i współaut. 2002). VAN OVERVELD i MATTHYSEN (2010) wykazali, że cechy osobowości wpływaja na przestrzenną odpowiedź osobnika. Osobniki szybkie porzucały karmniki, w których zaniechano nowych dostaw pokarmu i przenosily poszukiwania na obszary oddalone od tych karmników, podczas gdy osobniki wolne korzystały $z$ alternatywnego źródła pokarmu $\mathrm{w}$ pobliżu miejsca wcześniejszego dokarmiania. Autorzy sugeruja, że osobniki szybkie i wolne, oprócz zasięgu poszukiwań, może też różnić sposób korzystania ze zdobytych wcześniej informacji i wykorzystanie posiadanego doświadczenia $\mathrm{w}$ radzeniu sobie z różnymi zmianami zachodzacymi w siedlisku. Rzeczywiście, po jednym lub dwóch dniach od zakończenia uzupełniania pokarmu w karmnikach, szybkie osobniki gwałtownie przemieszczały się $\mathrm{w}$ inne miejsca, znane im sprzed dokarmiania. Osobniki wolne przemieszczały się na mniejsza skalę i w sposób stopniowy. Ponadto, osobniki szybko eksplorujace środowisko znacznie rzadziej powracały do miejsc, w których wcześniej znalazły pokarm, niż młode ptaki wolno eksplorujace (VAN OVERVELD i MATTHYSEN 2013). Wyniki te wskazuja, że zachowania eksploracyjne ptaków w nowym środowisku, odzwierciedlaja różnice $\mathrm{w}$ gromadzeniu informacji między osobnikami szybkimi i pobieżnymi oraz wolnymi i dokładnymi. Świadcza również o tym, że omawiane typy osobowości różnią się zasadami, jakimi kieruja się ptaki przy podejmowaniu decyzji: osobniki wolne opuszczają żerowisko na podstawie bardziej szczegółowych informacji na temat środowiska i/lub zasobów pokarmowych, a osobniki szybkie kieruja się pobieżna ocena sytuacji. Najnowsze badania dowodza, że za- chowania eksploracyjne u szpaków Sturnus vulgaris sa powtarzalne, zarówno $\mathrm{w}$ różnych sezonach (wiosna i jesienia), jak i w kolejnych latach (THYs i współaut. 2017).

Wskaźnikiem osobowości może być również poziom agresji. Wyniki badań przeprowadzonych na bogatkach potwierdzaja powtarzalność zachowań agresywnych (VERBEEK i współaut. 1996). Test polegający na umieszczaniu samców o znanym typie eksploracji $\mathrm{w}$ jednej klatce wykazał, że najczęściej wygrywa samiec, który podejmuje walkę, a poziom agresji jest skorelowany ze sposobem eksplorowania środowiska.

Najczęstszą odpowiedzią ptaków na zagrożenie jest ucieczka. Z uwagi na to, że dystans ucieczki, czyli minimalna odległość na jaka dany osobnik dopuszcza do siebie potencjalnego wroga, różni się między poszczególnymi osobnikami, można założyć, że ma ona zwiazek $z$ indywidualna skłonnościa ptaka do podejmowania ryzyka. Ocenę dystansu ucieczki można więc traktować jako jeden $z$ elementów osobowości osobnika. Dystans ucieczki opiera się na prostym rachunku zysków i strat. Jeśli ucieczka może przynieść duże straty, np. miejsce, w którym zwierzę się znajduje obfituje w pokarm, wtedy jego dystans ucieczki będzie krótszy, ponieważ $z$ uwagi na dobre warunki warto jest podjąć większe ryzyko. Jeżeli natomiast ucieczka może przynieść większa korzyść niż pozostanie $\mathrm{w}$ danym miejscu, wtedy dystans ucieczki będzie dłuższy, np. w sytuacji, gdy obecne miejsce nie zapewnia kryjówki (YDENBERG i DiLl 1986). Powtarzalność dystansu ucieczki na poziomie osobniczym wykryto u pójdźki zmiennej Athene cunicularia (CARRETE i TElla 2010) i edredona Somateria mollissima (SELTMANN i współaut. 2012). W badaniach przeprowadzonych na amadyńcach Erythrura gouldiae sprawdzano, po jakim czasie od zaprezentowania sylwetki drapieżnika zbliżajacej się w stronę klatki, żerujący w niej osobnik powróci do spożywania pokarmu. Również te testy potwierdzaja wysoka powtarzalność skłonności ptaków do podejmowania ryzyka (Williams i współaut. 2012).

Zachowania innowacyjne, to nowe zachowania pojawiajace się u osobnika w odpowiedzi na nieznane lub znane bodźce, będące modyfikacją innych zachowań (GREENBERG 2003). Innowacyjność wydaje się być dobrym wskaźnikiem osobowości, bowiem ptaki, które wykazały się innowacyjnym zachowaniem sa bardziej skłonne do takich zachowań $\mathrm{w}$ przyszłości, a powtarzalność $\mathrm{w}$ czasie jest głównym kryterium cechy osobowości (PFEFFER i współaut. 2002). Co więcej, nowe zachowanie rozwijane jest zawsze przez pojedynczego osobnika (PFEFFER i współaut. 
2002). Jest to zatem cecha zróżnicowana międzyosobniczo. Wyniki badań wskazuja, że widoczny $u$ bogatek i modraszek Cyanistes caeruleus wzrost wydajności w rozwiazywaniu nowych problemów w większych grupach nie zmniejsza neofobii, czyli strachu osobników przed nowościa, ale zmniejsza ryzyko zostania ofiara drapieżnictwa (MoRAND-FERRON i QUEEN 2011). Wykazano, że międzyosobnicze zróżnicowanie innowacyjności i strachu przed nowością nie różnią się między sobą w (WEBSTER i LEFEBVRE 2001). Stopień neofobii, nawet w sytuacjach głodu, różni się nie tylko międzyosobniczo, ale i międzygatunkowo (TRYJANOWSKI i współaut. 2015). Badania prowadzone na bogatkach potwierdziły powtarzalność umiejętności rozwiazywania przez ptaki problemów i wykazywały stałość tej cechy niezależnie od kondycji i płci osobnika (COLE i współaut. 2011). Co więcej, cecha ta jedynie w niewielkim stopniu była zależna od wieku (COLE i współaut. 2011). Wyniki nie potwierdziły jednak zależności między neofobia a innowacyjnością. Autorzy spekulują, że mogło to wynikać $z$ obniżonej reakcji ptaków w sytuacji, kiedy nowy obiekt znajduje się w nowym otoczeniu, w stosunku do sytuacji, w której nowy obiekt znajduje się w znanym otoczeniu. Warto dodać, że w eksperymentach dotyczących innowacyjności tym, co motywuje zwierzę do rozwiazania problemu, czyli do zachowań innowacyjnych, jest zwykle pokarm, choć, jak opisano to w dalszej części, może to być niekiedy przymus karmienia potomstwa (CAUCHARD i współaut. 2013).

Osobowość może być wyrażana również poprzez śpiew. GARAMSZEGI i współaut. (2008) sugeruja, że istnieją przynajmniej trzy powody, dla których osobowość jest wyrażana w śpiewie. Po pierwsze, śsiew wabi nie tylko samice, ale również drapieżniki, zatem można się spodziewać, że osobniki, które śpiewają długie piosenki w wyeksponowanych miejscach sa skłonne do ryzyka. Po drugie, piosenki danego osobnika moga się zmieniać pod wpływem śpiewu innych osobników i co za tym idzie, odważne ptaki, szybciej eksplorujace, będa miały kontakt $z$ większa liczbą bodźców wokalnych, dając im większe możliwości poszerzenia repertuaru. Po trzecie, stresowe sytuacje maja wpływ na metabolizm osobnika, w związku z czym, koszty energetyczne ponoszone przez ptaka podczas śpiewania będa znaczaco wpływać na jego odpowiedź na stres wynikajacy $z$ ryzykownej sytuacji. U muchołówki białoszyjej Ficedula albicollis wykazano, że samce odważne śpiewaja w miejscach bardziej wyeksponowanych, natomiast nieśmiałe wybieraja miejsca bar- dziej ukryte, natomiast cechy piosenek nie wykazały silnego zwiąku $z$ osobowościa (GARAMSZEGI i współaut. 2008). U bogatek wykazano dodatnia korelację między liczba piosenek a eksploracyjnością, przy czym liczba ta zmieniała się $\mathrm{w}$ ciągu dnia, a także w różnych sezonach (NAGUIB i współaut. 2010).

Cechy behawioru ptaków mogą się odzwierciedlać w morfologii, przede wszystkim w ubarwieniu (DUCREST i współaut. 2008). Czyży Carduelis spinus $z$ większym czarnym krawatem na piersi eksplorowały środowisko szybciej, niezależnie od wieku, płci i wielkości osobnika (MATEOS-GoNZALEZ i SENAR 2012). U bogatek również potwierdzono powiąanie osobowości $Z$ ubarwieniem: osobniki $z$ większym czarnym krawatem na piersi intensywniej bronia gniazda (QUESADA i SENAR 2007), a intensywność obrony gniazda jest związana $z$ osobowością osobnika (HOLLANDER i współaut. 2008). Stwierdzono przy tym, że tylko cechy warunkowane przez obecność melaniny, a nie karotenoidów, wykazuja korelację $z$ intensywnością obrony gniazda (QUESADA i SENAR 2007). U puszczyków Strix aluco, samice ciemniej ubarwione znacznie częściej były agresywne w stosunku do ludzi podchodzacych pod ich gniazda (DA SILVA i współaut. 2013). Wyniki tych samych badań pokazały, że ptaki silniej reagowały wówczas, gdy w okolicy gniazda stawiano wypchanego puszczyka ciemno ubarwionego.

Czarnogłowe osobniki amadyńcach łapały się w sieci szybciej i szybciej podchodziły do nowego przedmiotu niż czerwonogłowe, co może wynikać $z$ tego, że czerwonogłowe osobniki kompensuja ekspozycję na drapieżców, wynikająca $z$ jaskrawego ubarwienia, nie podejmując ryzykownych zachowań (MetTKe-HofFMAN 2012). Zjawisko to można równiė̇ tłumaczyć struktura dominacji, w której czerwonogłowe osobniki dominuja nad czarnogłowymi (PRYKE 2007), stąd czarnogłowe osobniki moga kompensować sobie niższa pozycję socjalna ryzykowniejszymi zachowaniami. Takie zachowania moga przynosić korzyści np. dzięki szybszemu docieraniu do nowych źródeł pokarmu. Z drugiej strony, czerwonogłowe osobniki, same nie ryzykując, moga wykorzystywać skłonne do takich zachowań osobniki czarnogłowe, czerpiąc korzyści $z$ zasobów odnalezionych przez podporzadkowane osobniki czarnogłowe. W innych badaniach amadyńców wykazano jednak, że osobniki czerwonogłowe sa bardziej agresywne, wykazuja niższa neofobię i sa bardziej skłonne do podejmowania ryzyka niż osobniki czarnogłowe (WILliAMs i współaut. 2012). 


\section{EFEKT KONTEKSTU SYTUACYJNEGO A OSOBOWOŚC}

Cechy osobowości moga się zmieniać, jeżeli zmianie ulegaja przewidywania o własnej kondycji w przyszłości (ang. survival probability) (NicOlaus 2012). Ptaki, których szanse przeżycia maleja, szybciej eksploruja otocznie, co jest dowodem na istnienie tzw. osobowości adaptacyjnej, która kłóci się z ogólnie przyjętym modelem stałości cech osobowości zarówno w czasie, jak i niezależnie od zaistniałego kontekstu. Relacja „kontekst-zachowanie" może być rozpatrywana w dwojaki sposób: jako stopień, do jakiego zachowanie $\mathrm{w}$ danym kontekście jest skorelowane wśród osobników $z$ zachowaniem w jednym lub wielu innych kontekstach (ang. contextual generality), lub jako stopień do jakiego zachowanie danego osobnika, w odniesieniu do innych osobników, zmienia się w różnych kontekstach (ang. contextual plasticity) (STAMPS i GROOTHUIS 2010). Kontekst i jego wpływ na wyrażanie się osobowości w postaci mierzalnych cech jest kwestia kluczową. Wyniki badań wskazuja na to, że cechy osobowości sa warunkowane genetycznie i sa dziedziczone, ale na wytworzenie adaptywnego fenotypu (zespołu cech organizmu) wpływają również warunki środowiska (WILSON i CLARK 1994). Na przykład bogatki, które wolno eksplorowały środowisko w kontekście niesocjalnym (bez „towarzystwa”), stawały się odważniejsze będąc wśród innych osobników (VAN OERS 2005). Zatem osobniki o konkretnym typie osobowości nie stosuja jednej strategii we wszystkich sytuacjach, ale cały zestaw różnych strategii. W badaniach amadyńców wykazano, że osobowość może się zmieniać w zależności od osobowości partnera. Osobnik staje się bardziej nieśmiały, jeśli jego partner jest nieśmiały i odwrotnie (KING i współaut. 2015).

\section{KORELACJE MIEDZY RÓŻNYMI TYPAMI OSOBOWOSCI}

Skorelowane ze soba cechy osobowości nazywane sa syndromami behawioralnymi. U bogatek tempo eksploracji środowiska jest dodatnio skorelowane $z$ agresywnościa osobnika. W zdecydowanej większości starć, zarówno dwóch samców, jak i dwóch samic, walkę rozpoczynał i wygrywał osobnik szybko eksplorujacy (VERBEEK i współaut. 1996, DRENT i MARCHETTI 1999). W populacjach wróbla domowego Passer domesticus, zasiedlającego środowiska o różnym stopniu zurbanizowania, wykazano istnienie syndromu behawioralnego złożonego $z$ neofobii względem przedmiotu, skłonności do ryzyka i ogólnej aktywności u ptaków żyjących w siedliskach zurbanizowanych. U ptaków żyjacych na wsiach wykryto istnienie syndromu złożonego $z$ neofobii względem przedmiotu, neofobii względem nowego pożywienia, skłonności do ryzyka i ogólnej aktywności (BÓKONY i współaut. 2012). Z kolei u amadyńców skłonność do ryzyka i neofilia (czyli zainteresowanie nowościa) sa skorelowane wśród wszystkich osobników, natomiast agresja nie jest skorelowana ani ze skłonnością do ryzyka ani $z$ neofilia (WILLIAMS i współaut. 2012). We wspomnianych wcześniej badaniach szpaków wykazano, że szybkość eksploracji i towarzyskość (ang. sociability), choć sac powtarzalne w czasie i w różnych sezonach, nie sa ze soba skorelowane, a zatem nie tworza syndromu behawioralnego (THYs i współaut. 2017).

\section{OSOBOWOŚĆ A DOBÓR PŁCIOWY}

Cechy osobowości moga również być elementem branym pod uwagę przy doborze partnera (GABRIEL i BLACK 2012). Możemy wyróżnić dwa rodzaje kojarzenia się osobników: nielosowe i losowe. Kojarzenie nielosowe może być selektywne (dwa podobne fenotypy, ang. assortative mating) lub nieselektywne (inaczej negatywnie selektywne, gdzie kojarzą się dwa różne fenotypy, ang. disassortative mating).

Szybko eksplorujace samce bogatek wybierały samice o takim samym behawiorze, natomiast wolno eksplorujace samce nie wykazywały ścisłych preferencji, co wynikało prawdopodobnie $z$ tego, że potrzebuja one więcej czasu na stworzenie takich preferencji, niż osobniki szybko eksplorujące (GROOTHUIS i CARERE 2005). Do podobnych wniosków doszli GABRIEL i BLACK (2012) przeprowadzajac badania na modrosójce czarnogłowej Cyanocitta stelleri. Ptaki kojarzyły się pod względem takich samych cech behawioralnych, a zależność ta dotyczyła zarówno szybko, jak i wolno eksplorujacych osobników. Zeberki Taeniopygia guttata sa bardzo zróżnicowane w doborze partnera, zarówno pod względem częstości piosenek, jak i agresywności samców (FORSTMEIER i BIRKHEAD 2004).

Dlaczego samice nie wybieraja zawsze „najlepszych” samców? Samice nie różnia się możliwościami oszacowania jakości samca na podstawie jego sygnałów, ponieważ samica, która nie potrafi ocenić samca wybierałaby losowo samce o najwyższej i najniższej jakości (SCHUETT i współaut. 2010). U zeberek istniała jednak konsekwencja w wyborze samca, wykluczajaca taką losowość (FORSTMEIER i BIRKHEAD 2004), a zatem to osobowość samicy determinowała wybór partnera. Inne badania dowodza, że tylko szybko 
eksplorujące samce bogatek wykazują preferencje $\mathrm{w}$ stosunku do samic o tym samym typie eksploracyjności, a wolno eksplorujące samce nie wykazuja ich wcale. Autorzy uważaja, że wolno eksplorujące osobniki potrzebuja więcej czasu na stworzenie takich preferencji (GROOTHUIS i CARERE 2005). Ponadto, VAN OERS i współaut. (2004a) wskazuja $\mathrm{u}$ bogatek na powiazanie hierarchii dominacji $z$ osobowościa osobników, co niewątpliwie ma wpływ na kojarzenie się par.

Mimo istotnie większego sukcesu rozrodczego par skojarzonych selektywnie, często to właśnie nieselektywne kojarzenie par jest w populacjach bardziej powszechne. U bogatek zaobserwowano, że nieselektywny sposób kojarzenia się w pary jest najczęstszy, pomimo że takie pary nie wykazywały najwyższego sukcesu rozrodczego (DINGEMANSE i współaut. 2004). Przyczyna może być lepsza kondycja pośrednich fenotypów (czyli osobników o średniej wartości danej cechy), a uzyskanie takiego fenotypu możliwe jest przez skojarzenie rodziców o skrajnych fenotypach (czyli o skrajnej wartości danej cechy). Należy jednak zaznaczyć, że skojarzone pary osobników o skrajnie różnych cechach osiagały wyższy sukces rozrodczy wówczas, gdy rok nie obfitował w pokarm. Wykazano, że zachowania mniej odważne, jeśli chodzi o podłoże genetyczne, sa cechą dominujaca w stosunku do wysokiej odwagi, stąd nie opłaca się kojarzenie między ekstremalnymi osobowościami, bowiem wówczas potomstwo nie będzie miało średniej lub wysokiej wartości tej cechy (VAN OERS 2004b, SCHUETT 2008).

U muchołówek białoszyich (GARAMSZEGI i współaut. 2008) odważne samce, śpiewajace w miejscach bardziej wyeksponowanych, były wybierane przez samice w pierwszej kolejności. Samce te, być może były „lepszej jakości", ponieważ w przeciwnym wypadku nie mogłyby sobie pozwolić na takie ryzyko. Jak zatem należy rozumieć wpływ doboru płciowego na wytworzenie się cech osobowości? Według SchUETT i współaut. (2010), stałość cech behawioru może być generowana przez dobór płciowy wówczas, gdy samice preferuja samców niezmieniających się pod tym względem lub gdy takie samce lepiej radza sobie w rywalizacji $z$ innymi samcami. Dowodem jest m.in. behawioralna kompatybilność partnerów. Możliwe sa tutaj jedynie różnice w stopniu ekspresji jakiejś cechy osobowości. nie zaś różnice w jej stałości. Stałość w behawiorze jest kosztowna w zmiennym środowisku (ScHUETT i współaut. 2010), a koszt pożądanych zachowań jest wysoki, jeśli odzwierciedlaja one wysoka jakość osobnika (ZAHAVI 1975). Kluczowa jest prawdopodobnie przewidywalność zachowań, ponieważ umożliwia dobranie kompatybilne- go partnera, co ułatwia opiekę nad potomstwem czy synchronizacje zachowań. Ponadto, stałość cech zachowania ma pozytywne skutki dla kondycji. Po starciu dwóch samców i wygranej osobnika stale wykazującego wysoki poziom agresji, inne samce moga już nie stawać $z$ nim do walki, ponieważ założa, że maja małe szanse na wygrana (SCHUETT i współaut. 2010).

\section{OSOBOWOŚĆ A PRZEŻYWALNOŚĆ I SUKCES ROZRODCZY}

W badaniach bogatek wykazano, że pary, które osiagały najwyższy sukces rozrodczy składały się $z$ dwóch osobników szybko eksplorujacych lub dwóch wolno eksplorujących (Dingemanse i DE Goede 2004). Wielkość piskląt była negatywnie skorelowana $z$ zachowaniami eksploracyjnymi samicy, a osobowość samca nie miała wpływu na wielkość piskląt (DingEMANse i współaut. 2004). DiNGEMANSE i współaut. (2004) wykazali również zróżnicowana przeżywalność osobników o różnych osobowościach w poszczególnych latach i między płciami. Coroczne zmiany w presji selekcyjnej na cechy osobowości były zwiazane ze zróżnicowaniem warunków środowiska, czyli ilości dostępngo pokarmu (bukwia). Prawdopodobnie samice, $z$ założenia podporządkowane samcom, sa bardziej zaangażowane w konkurencje o pokarm. Natomiast samce konkurują o terytorium. Co za tym idzie, przy niedoborze pokarmu, u samic preferowana będzie wyższa agresja (skorelowana z szybka eksploracją), zaś przy obfitości pokarmu agresja powodować będzie wyższą śmiertelność. Odwrotnie jest wśród samców. Agresywność będzie preferowana w latach obfitych w pokarm, kiedy walka o terytoria jest nasilona, a utrata terytorium może być realnym zagrożeniem. Natomiast niski poziom agresji będzie się lepiej sprawdzał w środowisku ubogim w pokarm. Wspomniany $\mathrm{w}$ poprzednim rozdziale system kojarzenia par wpływał na sukces rozrodczy i był zróżnicowany między latami obfitującymi w pokarm (gdy wyższy sukces odnosiły pary skojarzone takimi samymi fenotypami) i tymi uboższymi (gdy osobniki w parze miały różne fenotypy).

U błękitników meksykańskich Sialia mexicana (DUCKWORTH 2006) intensywna ochrona gniazda nie wpływa dodatnio na sukces rozrodczy, mimo że dużym zagrożeniem jest dla nich nadobniczka drzewna Tachycineta bicolor. Pośredni zwiąek $z$ obniżonym sukcesem rozrodczym miała agresja w konkurencji między dwoma samcami. Samce agresywne w konkurencji samiec-samiec dostarczały wysiadujacej samicy znacznie mniej pokarmu niż samce, które takiej agresji nie 
wykazywały. Z tym związana była zwiększona śmiertelność piskląt $\mathrm{w}$ czasie wiosennych śniegów i spadków temperatury, bowiem wówczas niedokarmione samice opuszczały gniazda $\mathrm{w}$ poszukiwaniu pożywienia. Odwrotnie jest u pasówek śpiewnych Melospiza melodia, gdzie wysoki poziom agresji u samców ma pozytywny wpływ na sukces lęgowy (SCALES i współaut. 2013). U modrosójek czarnogłowych sukces okazał się być wyższy wśród osobników wolno eksplorujących i mało skłonnych do ryzyka (GABRIEL i BLACK 2012). PATRICK i BROWNING (2011) wykazali natomiast, że zachowania eksploracyjne rodziców nie wpływaja na intensywność karmienia piskląt.

U zeberek ciężar ciała potomstwa jest pozytywnie skorelowana $z$ zachowaniami eksploracyjnymi rodziców. Badania tego gatunku pokazały, że jeśli ojciec był wolno eksplorujący, a matka szybko eksplorujacca, to kondycja ich potomstwa była gorsza. Odwrotna sytuacja nie wpływała na kondycje młodych. Podobne wyniki uzyskano w przypadku agresji. Co ciekawe, wykryto zależność sukcesu rozrodczego od stałości behawioru rodziców (SCHUETT i współaut. 2011). Inne badania wykazały, że sukces rozrodczy szybko eksplorujących samców zeberek w warunkach wolierowych jest wyższy niż wolno eksplorujących, a także podejmuja one więcej prób lęgu i odchowuja więcej młodych (MCCOWAN i współaut. 2014). NicOlaUs i współaut. (2015) stwierdzili, że reaktywne i aktywne (syndrom behawioralny odwagi i agresji) samice bogatki różnia się możliwościami odchowania lęgu. Reaktywne samice lepiej radza sobie $z$ naturalna wielkościa lęgu, a aktywne skuteczniej odchowuja lęgi powiększone. Wśród przyczyn, dla których aktywne samice maja lęgi mniejsze niż optymalne, autorzy wymieniaja trzy: $z$ jakiegoś powodu ptaki dokonuja błędnej oceny środowiska, odchowanie potomstwa jest kosztowne energetycznie lub też inwestowałyby więcej w bieżąca reprodukcję, jeśli miałyby taka możliwość.

\section{OSOBOWOŚĆ A PRESJA SELEKCYJNA}

Działanie doboru naturalnego mierzymy badając korelację między cechą a kondycja osobnika (ENDLER 1986). Przede wszystkim, selekcja naturalna może być mierzona przeżywalnościa i liczba potomstwa. QUINN i współaut. (2009) stwierdzili słabe i zróżnicowane, w zależności od kontekstu, działanie doboru naturalnego na zachowania eksploracyjne samic bogatki. DINGEMANSE i współaut. (2004) w badaniach bogatek wykazali zróżnicowanie presji selekcyjnej w zależności od kontekstu, wieku i płci osobnika. In- nym przykładem moga być różnice w czasie złożenia pierwszego lęgu w sezonie. Szybko eksplorujace osobniki składaja jaja wcześniej niż wolno eksplorujace (GROOTHUIS i CARERE 2005), co skutkuje wyższym sukcesem rozrodczym tych pierwszych, ponieważ sa w stanie złożyć lęg po raz drugi w jednym sezonie. Również dominacje czy dyspersje możemy traktować jako wskaźniki kondycji osobnika (GROOTHUIS i CARERE 2005). Wśród samców bogatek na szczycie hierarchii stoja osobniki szybko eksplorujące, natomiast wśród nieterytorialnych młodych odwrotnie, na szczycie stoja wolno eksplorujace osobniki młodociane (Dingemanse i DE GOEDE 2004). Ponadto, szybko eksplorujace osobniki rozpraszaja się na większe odległości niż osobniki wolno eksplorujace (DINGEMANSE i współaut. 2003).

Wyniki badań bogatek wskazują na pewne rodzaje zachowań, mogace powodować mniejsze lub większe narażenie osobnika na pasożyty przenoszone przez wektory (czyli inne organizmy) i droga pokarmowa (DUNN i współaut. 2011). Malaria jest szeroko rozprzestrzeniona wśród ptaków choroba przenoszona wektorowo, wywoływana przez pierwotniaki z rodzaju Plasmodium i Leucocytozoon. Zainfekowane samce były częściej innowacyjne niż niezainfekowane, a w przypadku samic odwrotnie. Eksploracyjność samców nie różniła się istotnie między osobnikami zainfekowanymi i niezainfekowanymi. Natomiast zainfekowane samice eksplorowały szybciej niż niezainfekowane. Badania skłonności do ryzyka wykazały, że nie była ona znacząco powiazana $z$ zainfekowaniem osobnika lub jego brakiem. Zauważono jednak tendencję zainfekowanych samców do reagowania na bodziec częściej w stosunku do samców niezainfekowanych. Na tej podstawie autorzy wskazuja na nowy problem - selekcyjne konsekwencje pasożytnictwa moga działać na różne cechy behawioru niezależnie od siebie (DUNN i współaut. 2011).

\section{DETERMINOWANIE CECH OSOBOWOŚCI}

W badaniach mechanizmów kierujących powstawaniem różnorodności skorelowanych zachowań tworzacych osobowość, zwrócono uwage na powiazanie hormonów $z$ typami osobowości. Najczęściej badanym hormonem jest kortykosteron (COCKREM 2007). MARTINS i współaut. (2007) wykazali u zeberek powiazanie wydzielania kortykosteronu, będacego hormonem stresu, $z$ tak zwanymi sposobami radzenia sobie (ang. coping styles), $z$ zachowaniami eksploracyjnymi i $z$ podejmowaniem ryzyka. W teście eksploracyjności zarówno w nowym otoczeniu, jak i $z$ nowym 
przedmiotem, wykazano brak zwiąku stężenia kortykosteronu we krwi $z$ eksploracyjnością, ale tylko w przypadku linii ptaków o niskim jego poziomie. W teście skłonności do ryzyka ptaki o wysokim poziomie kortykosteronu wykazywały krótszy czas ponownego podejścia do karmnika.

Konflikty socjalne wywołuja reakcję na stres majaca wpływ na behawior i fizjologię osobników. W badaniach bogatek wykorzystano ten fakt, aby sprawdzić różnice w odpowiedzi na stres osobników o różnym typie eksploracyjności (CARERE i współaut. 2003). Zgodnie $z$ przewidywaniami, wyższy poziom kortykosteronu wykazały ptaki wolno eksplorujace. Natomiast u ptaków szybko eksplorujacych nie znaleziono zależności między typem osobowości a poziomem hormonów (CARERE i współaut. 2003). Zależność między aktywnościa osi podwzgórze-przysadka-nadnercza jest skorelowana $z$ eksploracyjnościa i korelacja ta jest odwrotnie proporcjonalna (BAUGH i współaut. 2012). GARAMSZEGI i współaut. (2012) badali natomiast muchołówki białoszyje w celu wykazania plejotropowego (czyli mającego więcej niż jeden efekt) działania kortykosteronu, zwiazanego $z$ całym syndromem behawioralnym: unikaniem nowości, agresją i skłonnościa do ryzyka. Autorzy założyli, że sekrecja tego hormonu powinna być skorelowana i tak samo ukierunkowana w przypadku każdego elementu syndromu behawioralnego. Nie udało się jednak potwierdzić związku między aktywnością osi podwzgórze-przysadka-nadnercza a unikaniem nowości, jak również $z$ agresją. Jako jedna $z$ przyczyn otrzymania takich wyników autorzy wymieniaja możliwość reagowania przez osobniki na stres zarówno poprzez procesy fizjologiczne, jak i poprzez behawior. Stad sytuacje stresowe, które moga być przez osobnika kontrolowane behawioralnie, np. przez ucieczke, nie musza wywoływać wzrostu sekrecji kortykosteronu. Innym hormonem często branym pod uwage w badaniach behawioralnych jest testosteron. U samców wróbli domowych nie stwierdzono jednak korelacji między zachowaniami eksploracyjnymi a produkcja testosteronu (MUTzEL i współaut. 2011). Podobnie KRALJ-FIŠER i współaut. (2009), nie stwierdzili zależności między stężeniem testosteronu we krwi a agresywnościa u gegawy $A n-$ ser anser.

Oprócz badania hormonów jako potencjalnego mechanizmu powstawania cech osobowości, przetestowano również podłoże genetyczne wykorzystujacc techniki molekularne. Wytypowano gen $D R D 4$, odpowiedzialny za ekspresje receptora dopaminowego $\mathrm{D}_{4}$, jako prawdopodobnie kluczowy dla powstawania osobowości u ludzi. KLUEN i współaut. (2012) w badaniach polimorfizmu genu $D R D 4$, nie stwierdzili jednak zależności między zachowaniami eksploracyjnymi osobników a polimorfizmem DRD4. Korelację wykazano natomiast w przypadku szybkości ucieczki, która związana była $z$ polimorfizmem pojedynczego nukleotydu DRD4-SNP905. Ptaki o genotypie $z$ para alleli GG miały zdecydowanie dłuższy czas ucieczki niż te o genotypach GA i AA. W badaniach na liniach bogatek wyselekcjonowanych i niewyselekcjonowanych $z$ naturalnej populacji, wykryto polimorfizm pojedynczego nukleotydu DRD4-SNP830. Częstość allelu SNP830T była niższa u ptaków wolno eksplorujacych niż u szybko eksplorujących. Ptaki wolno eksplorujące różniły się znacząco od niewyselekcjonowanych częstością występowania SNP830: w wyselekcjonowanej linii ptaków wolno eksplorujacych genotypy SNP830T/T i SNP830C/T były rzadsze niż wśród osobników niewyselekcjonowanych. Autorzy sugeruja, że może to wynikać $z$ faktu, że mała populacja ptaków wyselekcjonowanych podlega silnemu wpływowi efektów losowych, jak efekt założyciela czy dryf genetyczny. Ptaki niewyselekcjonowane o genotypie SNP830C/C eksplorowały wolniej niż heterozygoty SNP830C/T i homozygoty SNP830T/T. $\mathrm{Na}$ tej podstawie zdefiniowano dominację allelu SNP830T nad allelem SNP830C (FIDLER i współaut. 2007). KORSTEN i współaut. (2010) badali ten sam gen u bogatek $z$ czterech dzikich populacji. Częstość występowania poszczególnych genotypów nie różniła się między poszczególnymi populacjami. Natomiast populacje te różniły się między soba częstością występowania poszczególnych typów eksploracyjności. Tylko w dwóch wykazano korelację między eksploracyjnościa a polimorfizmem w genie SNP830.

Wyniki badań przeprowadzonych w ostatnich latach wskazuja również, że na rozwój konkretnego typu osobowości wpływa dieta $\mathrm{w}$ okresie postnatalnym. U zeberek mała dostępność mikroelementów w diecie piskląt zmniejsza odwage samców w dorosłym życiu, ale nie ma wpływu na neofobię i odpowiedź na stres. U samic nie wykryto natomiast żadnej zależności. Z kolei jeśli niedobory mikroelementów wystapią w czasie dojrzewania płciowego, to zredukowana jest neofobia $i$ odpowiedź na stres w dorosłym życiu u obu płci. U samic zaobserwowano wzrost agresji niezależnie od tego, na którym etapie rozwoju wystapiły braki w diecie (NOGUERA i współaut. 2015). VAN OERS i współaut. (2015) przeprowadzili podobne badania bogatek i stwierdzili, że nie ilość pająków, ale gassienic dostarczanych pisklętom wpływała dodatnio na szybkość eksplorowania środowiska w późniejszym życiu. Na rozwój osobowości 
wpływ może mieć także presja pasożytów. U krzyżówki Anas platyrhynchos rozwój cech osobowości zależy od perturbacji w układzie immunologicznym na wczesnym etapie rozwoju tych ptaków (BUTLER i współaut. 2012).

\section{KIERUNKI PRZYSZŁYCH BADAŃ}

STAMPS i GROOTHUIS (2010) sugeruja, że do pełnego zrozumienia funkcji osobowości w świecie zwierzat niezbędne jest zrozumienie powstawania osobowości. Dotychczasowe rozważania na temat rozwoju osobowości zwierzat maja jedynie charakter hipotetyczny i nie sa nadal naukowo potwierdzone. STAMPS i GROOTHUIS (2010) proponuja przeprowadzenie badań dotyczacych zmian w osobowości w toku całej ontogenezy. Eksperymenty te, chociaż sa znacznie bardziej czasochłonne, umożliwiłyby zweryfikowanie częstego w badaniach założenia, że okresowo stabilne cechy sa również stabilne w całym życiu. W obliczu nowych badań potwierdzających hipotezę „adaptacyjnej osobowości", długoterminowe eksperymenty mogłyby rzucić nowe światło na funkcję i charakter cech osobowości. Potwierdzenie tej hipotezy może być bodźcem nawet do przedefiniowania terminu osobowość.

Zrozumienie mechanizmu powstawania relacji osobowość-kontekst i samego funkcjonowania osobowości miałoby duże znaczenie dla innych badań. Być może rzuciłoby więcej światła na opisane, lecz nie do końca zrozumiane, zjawisko doboru płciowego czy selekcji naturalnej ze względu na osobowość. Innym ważnym aspektem jest mała różnorodność badanych gatunków. Już na obecnym etapie rozwoju tej gałęzi nauki zauważamy, że różnice międzygatunkowe sa ogromne i być może nie należy ekstrapolować wszystkich wyników badań na pozostałe gatunki ptaków.

Choć interdyscyplinarność tej dziedziny wymaga od ekologów behawioralnych szerokiej wiedzy i umiejętności, to jednak postęp jaki dokonał sie $\mathrm{w}$ tej dziedzinie $\mathrm{w}$ przeciagu ostatnich dwóch dekad jest zdumiewajacy i wart śledzenia. Należy pamiętać, że poznanie funkcji i mechanizmów, zarówno powstawania, jak i działania osobowości, nie tylko będzie stanowiło źródło wiedzy dla przyszłych ekologów behawioralnych czy psychologów zwierzat, ale również przyczyni się do lepszego zrozumienia osobowości u ludzi, u której podstaw, mimo jej wielkiej złożoności, stoja być może te same czynniki co u innych zwierzat.

\section{PODZIEKKOWANIA}

Ogromne podziękowania składam tragicznie zmarłemu Marcinowi Antczakowi. Za in- spirację i pomoc, bez których ta praca by nie powstała. Dziękuję również Łukaszowi Dylewskiemu, Marcinowi Tobółce oraz anonimowemu recenzentowi za konstruktywne komentarze.

\section{Streszczenie}

W latach 90. XX w. nastapił intensywny rozwój badań nad osobowościa zwierząt, w których szczególnie często wykorzystanym modelem sa ptaki. Opisano wiele wyznaczników osobowości u różnych gatunków, wśród których zwykle analizuje się sposób eksploracji środowiska, śpiew, poziom agresji, a także morfologiczne wyznaczniki osobowości takie jak ubarwienie. Wciąż jednak badacze borykaja sie $\mathrm{z}$ wieloma problemami, jak choćby efekt kontekstu. Podejmowane są także próby odnalezienia związków pomiędzy osobowościa osobnika a doborem płciowym czy sukcesem rozrodczym. Celem niniejszego artykułu jest przedstawienie aktualnego stanu wiedzy na temat osobowości ptaków, a także kierunków przyszłych badań zwiazanych $z$ tym zjawiskiem.

\section{LITERATURA}

Baugh A. T., Schaper S. V, HaU M., Cockrem, J. F., DE Goede P., VAN OeRS K., 2012. Corticosterone responses differ between lines of great tits (Parus major) selected for divergent personalities. Gen. Comp. Endocr. 175, 488-494.

BÓKONY V., Kulcsár A., TÓTH Z., LIKER A., 2012. Personality traits and behavioral syndromes in differently urbanized populations of house sparrows (Passer domesticus). PloS One 7, e36639.

BuRTT H. E., GILTZ M., 1973. Personality as a variable in the behaviour of birds. Ohio J. Sci. 73, 65-82.

Butler M. W., ToOmey M. B., McGraw K. J., ROWE M., 2012. Ontogenetic immune challenges shape adult personality in mallard ducks. Proc. R. Soc. B 279, 326-333.

Carere C., Groothuis T. G. ., Möstl E., DaAN S., KOOlHAAS J., 2003. Fecal corticosteroids in a territorial bird selected for different personalities: daily rhythm and the response to social stress. Horm. Behav. 43, 540-548.

CARRETE M., TELLA J. L., 2010. Individual consistency in flight initiation distances in burrowing owls: a new hypothesis on disturbance-induced habitat selection. Biol. Lett. 6, 167170.

CAUChard L., Boogert N. J. Lefebvre L., Dubois F., Doligez B., 2013. Problem-solving performance is correlated with reproductive success in a wild bird population. Anim. Behav. 85, 19-26.

COCKREM J. F., 2007. Stress, corticosterone responses and avian personalities. J. Ornithol. 148, 169-178.

COlE E. F., CRAM D. L., QuinN J. L., 2011. In dividual variation in spontaneous problem -solving performance among wild great tits. Anim. Behav. 81, 491-498.

Da Silva A., Brink V., Emaresi G., LuZi E., Bize P., DREISS A. N., Roulin A., 2013. Melanin-based colour polymorphism signals aggressive personality in nest and territory defence in the tawny owl (Strix aluco). Behav. Ecol. Sociobiol. 67, 1041-1052.

Dingemanse N. J., DE GoEDE P., 2004. The relation between dominance and exploratory be- 
havior is context-dependent in wild great tits. Behav. Ecol. 15, 1023-1030.

Dingemanse N. J., Botha C., DREnT P. J., VAN OERSA K., VAN NOORDWIJKA A. J., 2002. Repeatability and heritability of exploratory behaviour in great tits from the wild. Anim. Behav. 64, 929-938.

Dingemanse N. J., Both C., VAN NoORdwiJK A. J., RutTen A. L., DRENT P. J., 2003. Natal dispersal and personalities in great tits (Parus major). Proc. R. Soc. B. 270, 741-747.

Dingemanse N. J., BOTH C., DRENT P. J., TinBERGEN J. M., 2004. Fitness consequences of avian personalities in a fluctuating environment. Proc. R. Soc. B. 271, 847-52.

DRENT P. J., MARCHETTI C., 1999. Individuality, exploration and foraging in hand raised juvenile great tits standard tests. [W:] Proceedings of the 22nd International Ornithological Congress. ADAMS N. J., SlOTOW R. H. (red.). Durban, Birdlife South Africa, Johannesburg, 896-914

DUCKWORTH R. A., 2006. Behavioral correlations across breeding contexts provide a mechanism for a cost of aggression. Behav. Ecol. 17, 1011-1019.

Ducrest A. L., Keller L., Roulin A., 2008. Pleiotropy in the melanocortin system, coloration and behavioural syndromes. Trends Ecol. Evol. 23, 502-510.

DunN J. C., COlE E. F., QuinN J. L., 2011. Personality and parasites: sex-dependent associations between avian malaria infection and multiple behavioural traits. Behav. Ecol. Sociobiol. 65, 1459-1471.

ENDLER J. A., 1986. Natural selection in the wild. Princeton University Press, Princeton, NJ.

FidleR A. E., VAN OERS K., DRENT P. J., KUHN S., Mueller J. C., Kempenaers B., 2007. Drd4 gene polymorphisms are associated with personality variation in a passerine bird. Proc. $\mathrm{R}$. Soc. B. 274, 1685-1691.

FORSTMEIER W., BIRKHEAD T. R., 2004. Repeatability of mate choice in the zebra finch: consistency within and between females. Anim. Behav. 68,1017-1028

GABRIEL P. O., BLACK J. M., 2012. Behavioural syndromes, partner compatibility and reproductive performance in Steller's jays. Ethology 118, 76-86.

GaramsZegi L. Z., Eens M., TÖRÖK J., 2008. Birds reveal their personality when singing. Plos One 3, e2647.

Garamszegi L. Z., Rosivall B., RetTenbacher S., MARKÓ G., ZSEBÖK S., SZÖLlÖSI E., EENS M., POTTI J., TÖRÖK J., 2012. Corticosterone, avoidance of novelty, risk-taking and aggression in a wild bird: no evidence for pleiotropic effects. Ethology 118, 621-635.

GosLING S., 2001. From mice to men: what can we learn about personality from animal research? Psychol. Bull. 121, 45-86.

GREENBERG R., 2003. The role of neophobia and neophilia in the development of innovative behaviour of birds. [W:] Animal innovation. READER S., LALAND K. (red). Oxford University Press, Oxford, 175-196

Groothuis T., CARERE C., 2005. Avian personalities: characterization and epigenesis. Neurosci. Biobehav. Rev. 29, 1-14.

Hollander, F. A., VAN OVERVEld, T., TOKKA, I., \& MATTHYSEN, E. 2008. Personality and nest defence in the great tit (Parus major). Ethology $114,405-412$.

King A. J., Williams L. J., MetTke-Hofmann C., 2015. The effects of social conformity on Gou- ldian finch personality. Anim. Behav. 99, 2531.

Kluen E., Kuhn S., Kempenaers B., Brommer J. E., 2012. A simple cage test captures intrinsic differences in aspects of personality across individuals in a passerine bird. Anim. Behav. 84, 279-287.

Korsten P., Mueller J. C., Hermannstädter C., Boumman K. M., Dingemanse N. J., Drent P. J., Liedvogel M., Matthysen E., Van Oers K., VAN OVERVELD T., PATRICK S. C., QUINN J. L., SHELDON B. C., TINBERGEN J. M., KempenAeRS B., 2010. Association between DRD4 gene polymorphism and personality variation in great tits: a test across four wild populations. Mol. Ecol. 19, 832-843.

KRALJ-FIŠER S., WEISS B. M., KOTRSCHAL K., 2009. Behavioural and physiological correlates of personality in greylag geese (Anser anser). J. Ethol. 28, 363-370.

Martins T. L. F., RoberTs M. L., Giblin I., HUXHAM R., EVANS M. R., 2007. Speed of exploration and risk-taking behavior are linked to corticosterone titres in zebra finches. Horm. Behav. 52, 445-453.

Mateos-Gonzalez F., Senar J. C., 2012. Melanin-based trait predicts individual exploratory behaviour in siskins, Carduelis spinus. Anim. Behav. 83, 229-232.

McCowan L. S., Rollins L. A., GRIFFith S. C., 2014. Personality in captivity: more exploratory males reproduce better in an aviary population. Behav. Process. 107, 150-157.

MetTKE-HofmANn C., 2012. Head colour and age relate to personality traits in Gouldian finches. Ethology 118, 906-916.

MORAND-FERRON J., QUINN J. L., 2011. Larger groups of passerines are more efficient problem solvers in the wild. Proc. Natl. Acad. Sci. USA 108, 15898-15903.

Mutzel A., Kempenaers B., Laucht S., DingemanSE N. J., DALE J., 2011. Circulating testosterone levels do not affect exploration in house sparrows: observational and experimental tests. Anim. Behav. 81, 731-739.

NAGUiB M., KaZEK A., Schaper S. V., VAN OeRS K., VISSER M. E., 2010. Singing activity reveals personality traits in great tits. Ethology $116,763-769$

NICOLAUS M., 2012. Experimental evidence for adaptive personalities in a wild passerine bird. Proc. R. Soc. B. 279, 4885-4892.

NicOlAUS M., MATHOT K. J., ARAYA-AJOY Y. G., Mutzel A., WiJMenga J. J., Kempenaers B., DingEMANSE N. J., 2015. Does coping style predict optimization? An experimental test in a wild passerine bird. Proc. R. Soc. B. 282, 20142405.

Noguera J. C., Metcalfe N. B., Surai P. F., MONAGHAN P., 2015. Are you what you eat? Micronutritional deficiencies during development influence adult personality-related traits. Anim. Behav. 101, 129-140.

PATRICK S. C., BRownING L. E., 2011. Exploration behaviour is not associated with chick provisioning in great tits. PLoS One 6, e26383.

PFEFFER K., Fritz J., KOTRSCHAL K., 2002. Hormonal correlates of being an innovative greylag goose, Anser anser. Anim. Behav. 63, 687-695.

PRYKE S. R., 2007. Fiery red heads: female dominance among head color morphs in the Gouldian finch. Behav. Ecol. 18, 621-627.

QUESADA J., SENAR J. C., 2007. The role of melanin- and carotenoid-based plumage coloration 
in nest defence in the great tit. Ethology 113, 640-647.

QUiNN J. L., PATRICK S. C., BOUWhUIS S., WilkiN T. A., SHELDON B. C., 2009. Heterogeneous selection on a heritable temperament trait in a variable environment. J. Anim. Ecol. 78, 1203-1215.

Réale D., Reader S. M., Sol D., McDougall P. T., Dingemanse N. J., 2007. Integrating animal temperament within ecology and evolution. Biol. Rev. Camb. Philos. Soc. 82, 291-318.

Scales J., Hyman J., Hughes M., 2013. Fortune favours the aggressive: territory quality and behavioural syndromes in song sparrows, $\mathrm{Me}$ lospiza melodia. Anim. Behav. 85, 441-451.

SCHUETT W., 2008. Sexual selection and personality in zebra finches, Taeniopygia guttata. https://ore.exeter.ac.uk/repository/handle/10036/68133.

SchueTT W., TREgEnZA T., DALL S. R. X., 2010 Sexual selection and animal personality. Biol. Rev. Camb. Philos. Soc. 85, 217-246.

SchuetT W., Dall S. R. X., Royle N. J., 2011. Pairs of zebra finches with similar "personal ities" make better parents. Anim. Behav. 81, 609-618.

Seltmann M. W., Öst M., JaAtinen K., AtKinson S., Mashburn K., Hollmén T., 2012. Stress responsiveness, age and body condition interactively affect flight initiation distance in breeding female eiders. Anim. Behav. 84, 889-896.

Stamps J., Groothuis T. G. G., 2010. The development of animal personality: relevance, concepts and perspectives. Biol. Rev. Camb. Philos. Soc. 85, 301-325.

Thys B., Eens M., Aerts S., Delory A., Iserbyt A., PINXTEN R., 2017. Exploration and sociability in a highly gregarious bird are repeatable across seasons and in the long term but are unrelated. Anim. Behav. 123, 339-348.

TRYJANOWSKI P., MORELli F., SKORKA P., GOŁAWSKI A., INDYKIEWICZ P., MøLler A., Mitrus C., WYSOCKI D., ZDUNIAK P., 2015. Who started first? Bird species visiting novel birdfeeders. Sci. Rep. 5, 11858.
VAN OERS K., 2005. Context dependence of personalities: risk-taking behavior in a social and a nonsocial situation. Behav. Ecol. 16, 716723.

VAN Oers K., DRent P. J., DE Goede P., VAN NoORDWIJK A. J., 2004a. Realized heritability and repeatability of risk-taking behaviour in relation to avian personalities. Proc. Royal Soc. $271,65-73$.

VAN OERS K., DREnT P. J., DE JONG G., VAN NOORDWIJK A. J., 2004b. Additive and nonadditive genetic variation in avian personality traits. Heredity 93, 496-503.

VAN Oers K., Kohn G. M., Hinde C. A., Naguib M., 2015. Parental food provisioning is related to nestling stress response in wild great tit nestlings: implications for the development of personality. Front. Zool. 12, S10.

Van Overveld T., MatThysen E., 2010. Personality predicts spatial responses to food manipulations in free-ranging great tits (Parus major). Biol. Lett. 6, 187-190.

VAN OVERVELD T., MATTHYSEN E., 2013. Personality and information gathering in free-ranging great tits. PloS One 8, e54199.

VERBEeK M. E. M., DE Goede P. DREnT P. J. WIEPKEMA P. R., 1999. Individual behavioural characteristics and dominance in aviary groups of great tits. Behaviour 136, 23-48.

WEBSTER S. J., LEFEBVRE L., 2001. Problem solving and neophobia in a columbiform-passeriform assemblage in Barbados. Anim. Behav. 62, 23-32.

Williams L. J., King A. J., MetTKe-HofmanN C. 2012. Colourful characters: head colour reflects personality in a social bird, the Gouldian finch, Erythrura gouldiae. Anim. Behav. 84, 159-165.

WILSON D. S., CLARK A., 1994. Shyness and boldness in humans and other animals. Trends Ecol. Evol. 9, 442-446.

YDENBERG R., DILL L., 1986. The economics of fleeing from predators. Adv. Study Behav. 16, 229-249.

ZAHAVI A., 1975. Mate selection - a selection for a handicap. J. Theor. Biol. 53, 205-214. 
KOSMOS Vol. 67, 2, 275-285, 2018

\title{
JOANNA T. WOŹNA
}

Institute of Zoology, Poznań University of Life Sciences, 71C Wojska Polskiego Str., 60-625 Poznań, E-mail: jtwozna@gmail.com

\author{
PERSONALITY IN BIRDS - THERETICAL ASSUMPTIONS, DIRECTIONS AND METHODS OF RESEARCH
}

\section{Summary}

Since 1990s we have observed intense progress in studies on animal personality, especially on birds treated as a model. Up to date many indicators of personality have been described for different species, among which usually there were analysed: manner of environment exploration, singing, aggression level, and also some morphological indicators, e.g. plumage. Still, researchers are facing many problems such as effect of context. There are also attempts to find relationship between personality and sexual selection, or breeding success. Aim of this article is to show the state of art in birds' personality studies, and directions for future research.

Key words: animal personality, birds, methods, personality traits 